The influence of the tag-along rights in the value of companies: an event study of the effects on

the market and service companies

\title{
Track: Corporate Finance and Financial Markets
}

William Eid Junior

Professor

FGV/EAESP

Escola de Administração de Empresas de São Paulo

Fundação Getúlio Vargas

Av. Nove de Julho $2029 \quad 10^{\circ}$ andar

São Paulo Brasil CEP 01313-902

Phone: 5511 3281-7899

Fax: 5511 3284-1789

weid@fgvsp.br

Indexing: Eid Jr, William

Ricardo Ratner Rochman

Professor

FGV/EAESP

Escola de Administração de Empresas de São Paulo

Fundação Getúlio Vargas

Av. Nove de Julho $2029 \quad 10^{\circ}$ andar

São Paulo Brasil CEP 01313-902

Phone: $55113281-7899$

Fax: 5511 3284-1789

rrochman@ fgvsp.br

Indexing: Rochman, Ricardo Ratner

Key words

Tag-along, event study, Brazil 
The influence of the tag-along rights in the value of companies: an event study of the effects on the market and service companies

\begin{abstract}
:
the aim of this work is to check the effect of granting tag-along rights to stockholders by analyzing the behavior of the return of the stock. To do so we carried out event studies for a group of 21 company stocks, divided into service provider companies and others, who granted this right to their stockholders after Law 10,303 was passed in October, 2001. In the test we used two models for estimating abnormal returns: adjusted to the market and adjusted to the risk and market. The results of the tests we carried out based on these models did not capture abnormal returns (surpluses), telling us that the tag-along rights did not affect the pattern of daily returns of the stocks of companies traded on BOVESPA (The Sao Paulo Stock Exchange). We did not expect this result because of the new corporate governance practices adopted by companies in Brazil.
\end{abstract}

\title{
1 Introduction
}

Corporate Governance is a theme that has aroused a great deal of interest because we know that differences in this area have an impact on the value of companies and consequently on the wealth of their stockholders. The already classic work of La Porta (1998) indicates that a level of protection for minority stockholders is reflected in the value of the stock, in other words, an increase in the level of rights offered to minority stockholders increases the value of the company. Tag-along is one of the rights that can be offered to the minority stockholder. It can be defined as the right of minority stockholders, in the event of the company being sold or taken private, to receive for their stock a value, the point of reference of which is the value paid to majority stockholders. Therefore the tag-along right is a way of aligning the interests of the different associates of a company.

In Brazil, just as in other markets, there has been a movement in favor of the good practices introduced by Corporate Governance. Brandão (2003) talks about the emergence of a national corporate governance movement, mentioning a series of facts that provide evidence of such. The first is the reformulation of the Companies Law (Law 10,303 of 10/31/01) that aimed at improving protection for minority stockholders. The second was the launch of new trading segments in Bovespa, with Corporate Governance levels I and II. The third fact refers to the launch in 2002 of the Capital Markets Master Plan, approved and accepted by a number of entities in the market. The BNDES' [National Development Bank] Incentive Program for Adopting Corporate Governance Practices is the fourth fact mentioned by the author. The fifth fact is the concern expressed by various participants in the market with those who have an interest in companies, the so-called stakeholders. The final fact to support the author's thesis is the emergence of proposals for creating a Code of Corporate 
Governance, coming from bodies like the CVM - the Securities Exchange Commission, - and IBGC - the Brazilian Institute for Corporate Governance.

In this atmosphere it is quite appropriate to question if these Corporate Governance practices are perceived by stockholders in Brazil as adding value. This work aims to reply in part to this question. In Brazil various companies listed on the Bovespa have granted the tag-along right over the last few months. We want to identify if there was any alteration in the value of these companies because this right was granted, in other words, if stockholders see it as something of value.

\section{Bibliographic review}

In trying to find an economic explanation for the existence of agreements between stockholders, among which we can include the right of tag-along, Chemla, Habib and Ljunggvist (2002) show that they are put together with the intention of avoiding renegotiation in an atmosphere where the value of companies depends on investments and mechanisms for transferring wealth between stockholders. Stockholder agreements preserve the incentives for making investments and minimizing transfers between stockholders.

In a similar conceptual discussion, Rabelo and Coutinho (2001) argue that an improvement in Corporate Governance practices is fundamental for the development of the capital market and that the successive crises through which the country has passed over the last 20 years have in some way or another hampered the development of these practices. They also show that the control of companies in Brazil is exercised by few stockholders and that protection of minority stockholders should be one of the objectives pursued by the regulatory bodies; this is one of the factors that will be able to increase the level of internal financing available to companies.

Different empirical studies have been carried out in Brazil over the last few years trying to identify the impact of alterations in the rights of minority stockholders on the value of the company.

Ribeiro Neto and Famá (2001) studied the impact of the New Corporation Law (emending Law 6404/76) approved by the House of representatives on March 28, 2001. This emending law altered some clauses of the Law that was in force at the time, such as the proportion between common and preferred stock, which went from a maximum of $2 / 3$ rds preferred to $50 \%$. The article that dealt with the valuation of stocks in case a stockholder withdrawing from the company or the company going private was also altered, in favor of an economic valuation of the stock. Also, and principally, a tag-along right of $80 \%$ of the value paid for the controlling block of stock in the case of the disposal of the company is included in the emending law. Using the Event Study methodology on the difference in price between the ordinary and preference stock of 35 companies and presuming that the new legislation is of benefit to ordinary stockholders, the authors conclude that; “Common stocks increased in value by $12.3 \%$ on average, while on average preferred stocks lost $0.4 \%$ of their value. Of 
the companies studied 77\% (27 companies) had some type of increase in the value of their common stocks. On the contrary the preferred stocks of nearly 51\% (18 companies) of the companies declined in value. As the facts show, common stocks increased in value nearly 8 times more than preferred stocks. ....Neverthelss, it is clear that the market has been reacting to the changes that might come about as a result of the new legislation".

Carvalho (2003) studies the effect of the migration of 22 companies to Bovespa levels I and II, by analyzing the impact of this migration on the price, volumes and liquidity of the companies. The author argues that voluntary adherence to Corporate Governance regimes that give greater protection to minority stockholders is an alternative to the imposition of legal rules, since the latter come up against resistance from economic groups that are in control of the companies because the value of their controlling share will fall with the imposition of greater protection for minority stockholders. The author finds a positive effect on the value of companies, in other words, there is an abnormal positive return around the event window. Nevertheless it is not possible to determine the size of this abnormal return since it is not clear how long the event window lasts. The author also notices that there was an increase in the volume negotiated, an increase in liquidity and a reduction in the sensitivity to macro-economic factors. In short, migration to Bovespa's levels I and II of Corporate Governance benefited the owners of stock in these companies.

Saito (2003) analyses the determinants of the difference in price between the common and preferred stocks of 53 companies listed on Bovespa, selected by criteria associated with their liquidity. One of the highlights in this study refers to the impact seen when the tag-along right was withdrawn by Law 9457 in May, 1997 and its reinstatement by Law 10,303 of October, 2001 (the same studied by Ribeiro Neto and Famá (2001) while it was still in the emendation stage). The result of this analysis confirms the importance of the rights granted to minority stockholders, since the prize of the right to vote is significantly altered in the two events, always in the direction to be expected from the theoretical framework.

It is important to emphasize that the empirical studies carried out in Brazil until now on corporate governance have used as an event occurrences of a general nature, such as the approval of a new law or the migration to levels of corporate governance. In this study we are proposing studying a specific event: the incorporation of the tag-along right for each one of the companies in the sample.

\section{Methodology}

In this work we have used the technique of events' study to evaluate the effect of the tag-along right in the price and return of the stocks of the companies in the sample.

The technique of event study starts with the hypothesis that a particular fact or event affects the value of the company and that this change in value is reflected by means of an abnormal return on the stocks of the company. Therefore the concept 
of an abnormal return is one of the most important in the event study. Considering that the price of a company's stocks and the market are continually subject to a great variety of factors, we need to choose an appropriate reference index to control the effects of those facts not related to the event being studied.

We can define the empirical model of the stock returns of the company for those periods in which the event did not occur in the following way:

$$
R_{i t}=B_{t} \cdot \beta_{i}+\varepsilon_{t}
$$

where

$R_{i t}=$ is the return of the stock $\mathrm{i}$ in the period $\mathrm{t}$;

$B_{t}=$ is the vector of independent variables, for example, the return of the market portfolio on date t; $\beta_{i}=$ is the vector of parameters, for example, beta of stock $\mathrm{i}$ in relation to the market portfolio; and $\varepsilon_{t}=$ is the random term with zero average.

For the periods in which the event occurred the empirical model is as follows:

$$
R_{i t}=B_{t} \cdot \beta_{i}+F G+\varepsilon_{t}
$$

where

$F=i$ s the vector of characteristics of the company influencing the impact of the event in the process of the return on the stock

$G=i$ is the vector of parameters measuring the influence of $F$ on the occurrence of the event.

In order to capture the change in the empirical model of returns we used the procedure proposed by Campbell, Lo and MacKinlay (1997), who described the main steps in the process for studying the impact of the event on the returns of the stock of the company as: definition of the event; selection of the sample; measurement of the sample return; procedure for estimating; test procedure; empirical results; interpretation and conclusions.

In this work we defined as an event the date of the approval of the tag-along right at an extraordinary, or ordinary general meeting of the stockholders of the company, after Law 10,303 of October 31, 2001 was passed.

In the Brazilian market we found 37 companies that met our definition of the event. We limited the study, however to those stocks that were traded in the 22 day period after the date of the event and the 102 days before the date of the event; this was 
necessary to estimate the parameters of the models and for the tests. Therefore the sample in this article is made up of the following 21 stocks traded on BOVESPA and their respective companies:

\begin{tabular}{|c|l|c|c|c|c|}
\hline \multirow{2}{*}{ Name } & Code & $\begin{array}{c}\text { Tag-Along } \\
\text { Date }\end{array}$ & $\begin{array}{c}\text { Tag-Along } \\
\text { Ord \% }\end{array}$ & $\begin{array}{c}\text { Tag-Along } \\
\text { Pref \% }\end{array}$ & Listing Level \\
\hline Bco Itau Holding & ITAU4 & $30 / 04 / 2002$ & 80 & 80 & Level 1 \\
\hline \multirow{2}{*}{ Bradesco } & BBDC3 & $17 / 12 / 2003$ & 80 & 100 & Level 1 \\
\cline { 2 - 6 } & BBDC4 & $17 / 12 / 2003$ & 80 & 100 & Level 1 \\
\hline \multirow{2}{*}{ Banco do Brasil } & BBAS3 & $07 / 06 / 2002$ & 100 & - & Traditional \\
\cline { 2 - 6 } & BBAS4 & $07 / 06 / 2002$ & 100 & - & Traditional \\
\hline Braskem & BRKM5 & $16 / 08 / 2002$ & 100 & 100 & Level 1 \\
\hline Celesc & CLSC6 & $17 / 06 / 2002$ & 100 & 100 & Level 2 \\
\hline Coteminas & CTNM4 & $21 / 08 / 2002$ & 80 & 80 & Traditional \\
\hline Duratex & DURA4 & $16 / 12 / 2002$ & 80 & 80 & Traditional \\
\hline Eternit & ETER3 & $27 / 12 / 2002$ & 80 & 80 & Traditional \\
\hline F Cataguazes & FLCL5 & $14 / 02 / 2003$ & 80 & 80 & Traditional \\
\hline Gerdau & GGBR4 & $30 / 04 / 2002$ & 100 & 100 & Level 1 \\
\hline Itausa & ITSA4 & $29 / 04 / 2002$ & 80 & 80 & Level 1 \\
\hline Marcopolo & POMO4 & $21 / 08 / 2002$ & 100 & 80 & Level 2 \\
\hline Net & PLIM4 & $02 / 05 / 2002$ & 100 & 100 & Level 2 \\
\hline Perdigão & PRGA4 & $17 / 12 / 2002$ & 80 & 80 & Level 1 \\
\hline Randon Part & RAPT4 & $10 / 12 / 2002$ & 80 & 80 & Level 1 \\
\hline Rhodia-Ster & RHDS3 & $23 / 04 / 2002$ & 80 & 80 & Traditional \\
\hline Sabesp & SBSP3 & $18 / 04 / 2002$ & 100 & - & New Market \\
\hline Ultrapar & UGPA4 & $22 / 03 / 2002$ & 100 & 100 & Traditional \\
\hline Weg & ELMJ4 & $18 / 11 / 2002$ & 80 & 80 & Level 1 \\
\hline & & & & \\
\hline
\end{tabular}

Table 1. Stocks and companies that go to make up the sample, the dates of the events, types of tag-along and listing segment for the stock on BOVESPA.

The tests we carried out were the following:

a) With the sample of 21 stocks without any type of segregation;

b) Segregating the service companies from the others;

c) Segregating the companies that granted $100 \%$ tag-along for the minority common stockholders of the others.

The companies considered as financial service providers or utilities are: Bco Itau Holding Financ, Bradesco, Banco do Brasil, Celesc, Itausa, Net, Sabesp, and Ultrapar.

The companies that granted tag-along of $100 \%$ for minority common stockholders are: Banco do Brasil, Braskem, Celesc, Gerdau, Marcopolo, Net, Sabesp, Ultrapar.

The data source for the quotation of prices was the 'Economática' system and the source of information about tag-along rights and the companies were BOVESPA and the 'Economática' system.

We noted that during 2002, after Law 10,303/01 was passed, companies granted or reinstated the right of tag-along to their stockholders and a large number of these companies are to be found in the differentiated listing segments on BOVESPA (Level 1, 2 and New Market) with regard to their concern with corporate governance. 
In an event study we need to define a period of time in which the data are used to estimate the parameters of the models employed; we call this the estimation window. In addition we defined a period around this window for testing the event for the model chosen; we called this the event window. We adopted an estimation window comprising 80 daily observations of the stock quotations or returns. The event window on the other hand can be 22,11 or 5 observations prior to and after the date of the event, exclusive.

We want to test the significance of the abnormal returns in a window of time around the date or the event, or test the null hypothesis that the expected value of the cumulative abnormal returns in the event window is equal to zero. Continuing with the study we first of all estimated the abnormal returns, ex-post, which can be obtained from the difference between the returns of the company observed in the event window and the expected return of the company supplied by the reference model. The estimation models of the abnormal returns can be divided into two major categories: statistical models that do not depend on economic financial argumentation and economic financial models.

Brown and Warner $(1980,1985)$ quote the main statistical models for estimating abnormal returns: models adjusted to the average; models adjusted to the market; and models adjusted to the risk and market. Kloeckner (1995) shows that the three statistical models present similar results when it comes to estimating abnormal returns.

Campbell, Lo and MacKinlay (1997) present the main economic financial models that we are based on pricing models such as CAPM (Capital Asset Pricing Model) or APT (Arbitrage Pricing Theory).

In this work we shall estimate the abnormal returns using the model adjusted to the market and the one adjusted to the risk and market. The Brazilian stock market in this study will be represented by the closing Brazil Index (IBrX), as calculated by BOVESPA and made up of the 100 most liquid stocks in the market.

In the return model adjusted to the market the abnormal returns are estimated from the difference between the stock return and the market portfolio return in the same period. In this way, for each stock we determined the abnormal returns in the period analyzed. Therefore the abnormal return of stock, "i" on date " $t$ " is given by:

$$
A R_{i t}=R_{i t}-R_{m t}
$$

where

$A R_{i t}=$ the abnormal return of stock $\mathrm{i}$ on date $\mathrm{t}$;

$R_{i t}=$ return of stock i on date $\mathrm{t}$;

$R_{m t}=$ return of the market on date $\mathrm{t}$.

Daily returns are obtained from the daily quotations of the closing price of the stocks that go to make up the sample, calculated in the following way: 


$$
R_{i t}=\ln \left(P_{i t}\right)-\ln \left(P_{i t-1}\right)
$$

where

$R_{i t}=$ the return of stock $\mathrm{i}$ on date $\mathrm{t}$;

$P_{i t}=$ closing quotation of stock $\mathrm{i}$ on date $\mathrm{t}$.

The premise of the model of returns adjusted to the risk and market is that the abnormal returns of the stocks can be seen from the difference between the individual returns observed and the returns calculated using a simple factor model. The simple factor model is estimated using the data from the estimation window and a linear regression by means of ordinary leasts squares. Therefore abnormal returns are given by:

$$
A R_{i t}=R_{i t}-\left(\alpha_{i}+\beta_{i} R_{m t}\right)
$$

where

$A R_{i t}=$ the abnormal return of stock $\mathrm{i}$ on date $\mathrm{t}$;

$R_{i t}=$ the return of stock i on date $\mathrm{t}$;

$\alpha_{i}=$ linear coefficient of regression of stock $\mathrm{i}$ in relation to the market return;

$\beta_{i}=$ angular coefficient of regression of stock $\mathrm{i}$ in relation to the market return;

$R_{m t}=$ market return on date $\mathrm{t}$.

The excess, or abnormal returns, are then accumulated in the event windows, in the variable cumulative abnormal return

(CAR), in the following way:

$$
\mathrm{CAR}_{-\mathrm{tat}}=\sum_{-t}^{t}\left(\sum_{i=1}^{N} \frac{A R_{i t}}{N}\right)
$$

where

$A R_{i t}=$ the abnormal return of stock $\mathrm{i}$ on date $\mathrm{t}$;

$N=$ number of stocks in the sample or sub - sample;

$t=$ event window.

To test the cumulative abnormal return we used the following statistic: 


$$
\text { Test }=\frac{\mathrm{CAR}_{-\mathrm{tat}}}{s(A R) \sqrt{2 \cdot t+1}}
$$

where

$C A R_{-t a t}=$ the cumulative abnormal return for the event period that goes from - $\mathrm{t}$ to $\mathrm{t}$; $\mathrm{s}(\mathrm{AR})=$ is the standard deviation of the abnormal returns of the companies in the control period prior to the event;

$t=$ event window.

\section{$4 \quad$ Results}

The methodology was used for the stocks in the sample considering the 2 abnormal return models presented, for event windows of 22, 11 and 5 trading days prior to and after the event date, for the sample of 21 service or non-service companies and for companies that did or did not grant $100 \%$ tag-along rights to their minority common stockholders. In every case the estimation window contained 80 trading days prior to the event window.

Because of space limitations we shall only present tables with the results of the general aggregation of the returns of the stocks in the sample in every period in the event window. The aggregation of the returns of each individual stock and the returns of the stocks in the sample for each date in the event window separately did not generate significantly statistical cumulative abnormal returns for the models adjusted to the market, or adjusted to the risk and market; nor did the sample of 21 companies, nor when we separated the sample into service companies, or those that granted 100\% tag-along rights. One possible reason for this is that the size of the sample, just 21 stocks, was a limiting factor as far as this test was concerned. The results grouped together for each type of model and size of event window are shown in the following tables:

\begin{tabular}{l|r|r|}
\hline \multicolumn{1}{|c}{$\begin{array}{c}\text { Grouping of windows and } \\
\text { stocks }\end{array}$} & $\begin{array}{r}\text { Model } \\
\text { Adjusted to } \\
\text { the market }\end{array}$ & $\begin{array}{c}\text { Adjusted to } \\
\text { the risk and } \\
\text { market }\end{array}$ \\
\hline $\begin{array}{l}\text { Average CAR } \\
\text { Stand. deviation of average CAR } \\
\text { t statistic }\end{array}$ & $-0,0381 \%$ & $-0,0711 \%$ \\
\hline
\end{tabular}

Table 2. Results of the grouping of abnormal returns between stocks and trading days in the event window of 22 days prior to and after, for the sample of 21 stocks. 


\begin{tabular}{|l|r|r|}
\hline \multicolumn{1}{|c|}{$\begin{array}{l}\text { Grouping of windows and } \\
\text { stocks }\end{array}$} & \multicolumn{2}{c|}{ Model } \\
\cline { 2 - 3 } & $\begin{array}{r}\text { Adjusted to } \\
\text { the market }\end{array}$ & $\begin{array}{c}\text { Adjusted to } \\
\text { the risk and } \\
\text { market }\end{array}$ \\
$\begin{array}{l}\text { Average CAR } \\
\text { Stand. deviation of average CAR } \\
\text { t statistic } \\
\text { p value of test } \mathbf{t}\end{array}$ & $-0,0260 \%$ & $-0,0472 \%$ \\
\hline
\end{tabular}

Table 3. Results of the grouping of abnormal returns between stocks and trading days in the event window of 11 days prior to and after, for the sample of 21 stocks.

\begin{tabular}{|l|r|r|}
\hline \multicolumn{1}{|c|}{$\begin{array}{l}\text { Grouping of windows and } \\
\text { stocks }\end{array}$} & \multicolumn{2}{c|}{ Model } \\
\cline { 2 - 3 } & $\begin{array}{r}\text { Adjusted to } \\
\text { the market }\end{array}$ & $\begin{array}{c}\text { Adjusted to } \\
\text { the risk and } \\
\text { market }\end{array}$ \\
$\begin{array}{l}\text { Average CAR } \\
\text { Stand. deviation of average CAR } \\
\text { t statistic } \\
\mathbf{p} \text { value of test } \mathbf{t}\end{array}$ & $0,1757 \%$ & $0,2129 \%$ \\
\hline
\end{tabular}

Table 4. Results of the grouping of abnormal returns between stocks and trading days in the event window of 5 days prior to and after, for the sample of 21 stocks.

\begin{tabular}{|c|c|c|}
\hline \multirow[b]{2}{*}{ Grouping of windows and stocks } & \multicolumn{2}{|c|}{ Model } \\
\hline & $\begin{array}{c}\text { Adjusted to the } \\
\text { market }\end{array}$ & $\begin{array}{c}\text { Adjusted to the risk } \\
\text { and market }\end{array}$ \\
\hline Average CAR & $-0.1581 \%$ & $-0.1071 \%$ \\
\hline Standard deviation of average CAR & $0.9356 \%$ & $0.9164 \%$ \\
\hline t statistic & -0.1690 & -0.1169 \\
\hline$p$ value of test $t$ & $86.582 \%$ & $90.694 \%$ \\
\hline
\end{tabular}

Table 5. Results of the grouping of abnormal returns between stocks and trading days in the event window of 22 days prior to and after, for the sample of stocks of service provider companies. 


\begin{tabular}{|l|c|c|}
\hline \multicolumn{1}{|c}{ Grouping of windows and stocks } & Adjusted to the & Adjusted to the risk \\
& market & and market \\
Average CAR & $-0.0397 \%$ & $0.0640 \%$ \\
\hline Standard deviation of average CAR & $1.0346 \%$ & $1.0060 \%$ \\
\hline t statistic & & 0.0636 \\
\hline p value of test $\mathbf{t}$ & -0.0384 & \\
\hline
\end{tabular}

Table 6. Results of the grouping of abnormal returns between stocks and trading days in the event window of 11 days prior to and after, for the sample of stocks of service provider companies.

\begin{tabular}{|c|c|c|}
\hline \multirow[b]{2}{*}{ Grouping of windows and stocks } & \multicolumn{2}{|c|}{ Model } \\
\hline & Adjusted to the & Adjusted to the \\
\hline & market & market and risk \\
\hline Average CAR & $0.2771 \%$ & $0.3603 \%$ \\
\hline Standard deviation of average CAR & $1.1745 \%$ & $1.1537 \%$ \\
\hline t statistic & 0.2359 & 0.3123 \\
\hline$p$ value of test $t$ & $81.35116 \%$ & $75.47919 \%$ \\
\hline
\end{tabular}

Table 7. Results of the grouping of abnormal returns between stocks and trading days in the event window of 5 days prior to and after, for the sample of stocks of service provider companies.

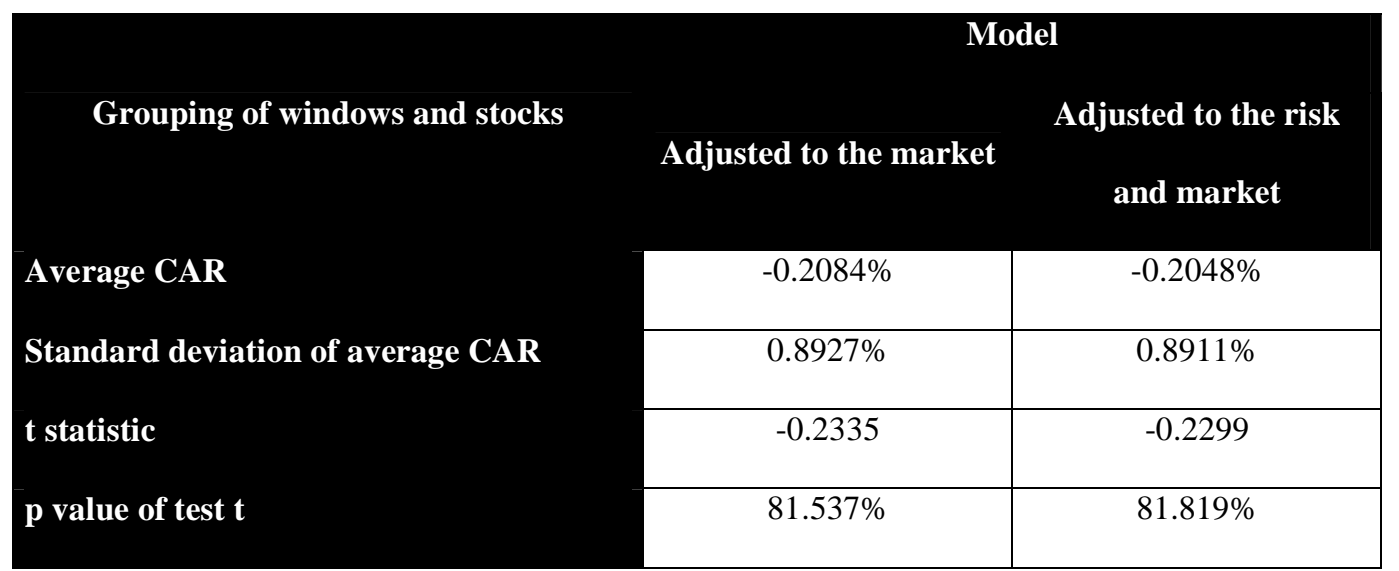

Table 8. Results of the grouping of abnormal returns between stocks and trading days in the event window of 22 days prior to and after, for a sample of stocks of companies that granted $100 \%$ tag-along rights to minority common stockholders. 


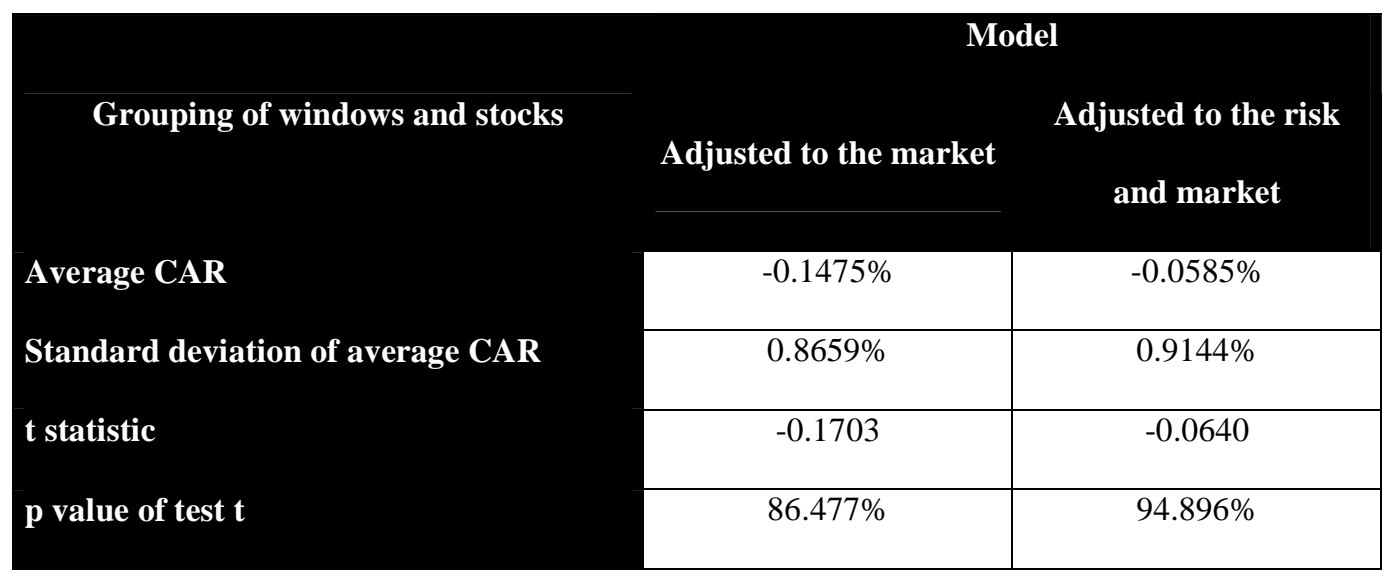

Table 9. Results of the grouping of abnormal returns between stocks and trading days in the event window of 11 days prior to and after, for a sample of stocks of companies that granted $100 \%$ tag-along rights to minority common stockholders.

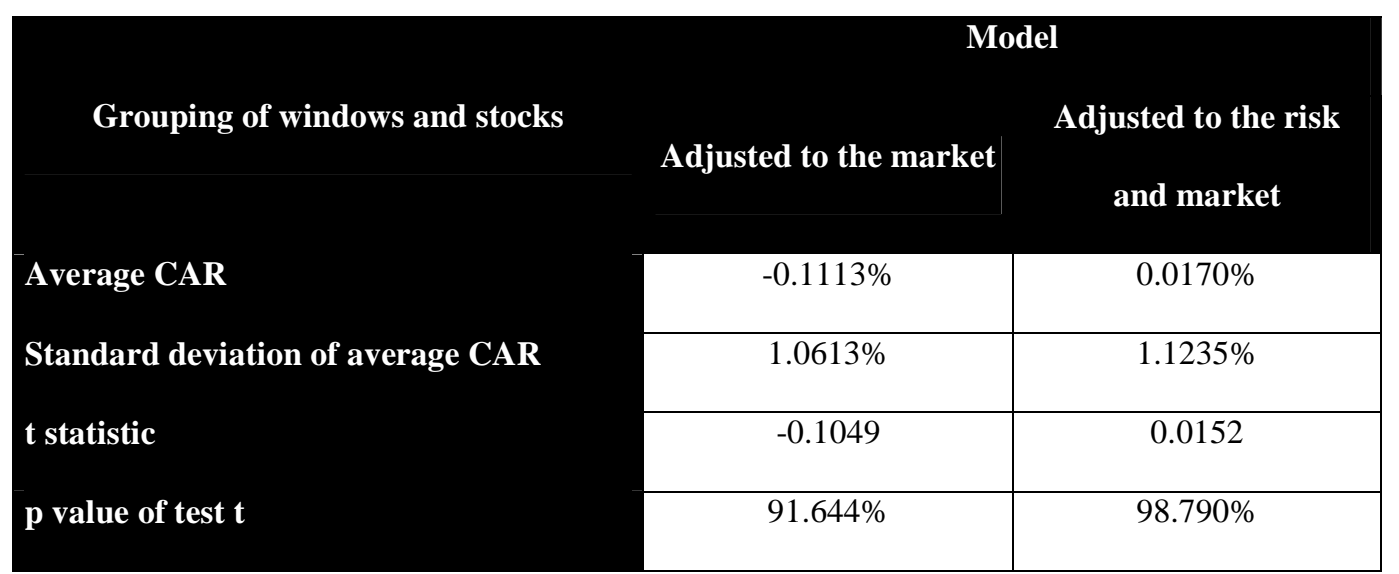

Table 10. Results of the grouping of abnormal returns between stocks and trading days in the event window of 5 days prior to and after, for a sample of stocks of companies that granted $100 \%$ tag-along rights to minority common stockholders.

We can see from the above tables that the results of the models adjusted to the market and adjusted to the risk and market are similar and consistent, as Kloeckner (1995) states, and in the case of this article these 2 models did not produce any significant result. Therefore we cannot reject the null hypothesis that the expected cumulative abnormal returns are equal to zero. We also carried out tests with the sub-samples of the companies that were not service providers and companies that did not grant $100 \%$ tag-along rights on common stocks and the results also did not produce any significant result as far as the presence of abnormal returns in the event windows are concerned.

\section{Conclusions}

The aim of this study is to analyze the effect of granting tag-along rights to stockholders in companies in general, or in service provider companies. To do so we carried out event studies for a series of stocks of companies that have recently granted this right to their stockholders. In the tests we used two models for estimating the returns. 
Based on the two models we used the results of the tests were not contradictory. The statistical models did not capture excess (abnormal) returns, indicating that the tag-along right did not affect the pattern of daily returns of the stocks of companies traded on BOVESPA. Because of the new practices of corporate governance used by Brazilian firms, we were not expecting to get this result.

The demand for better governance practices made by the international and national financial bodies, such as the BNDES, before they would provide investment funds, and the greater limits for buying stocks that have better governance made by pension funds, encouraged companies listed on BOVESPA to grant the tag-along right after the contents of Law 10,303/01 became public knowledge.

In the future we can redo this study with greater number of companies who gave the tag-along right and improve the parameter estimates of the Brownian geometric motion.

\section{References}

AdLER, R. J., FeldMAn R. E., TAQQU, M. S. (1998) “A Practical Guide to Heavy Tails”, Boston: Birkhäuser. BRANDÃo, M. M. (2003) “Uma Visão sobre a Governança Corporativa das Companhias Abertas Nacionais”, Tríade do Mercado, Apimec MG - www.apimecmg.com.br/nucleos/governanca/art03.pdf

BROWN, S., WARNER, J. (1980) "Measuring security price performance.", Journal of Financial Economics, v. 8, n.3.

BROWn, S., WARNER, J. (1985) "Using Daily Stock Returns. The case of Event Studies.”, Journal of Financial Economics, v. 4, p.3-31.

Campbell, J., Lo, A W., MacKinlay, A. (1997) The Econometrics of Financial Markets. New Jersey: Princeton

University Press.

ChEMla, G. ; HABIB, M. \& LJUNGQvist, A. (2002) “An Analysis of Shareholder Agreements”, Working Paper CLB-02-001, New York University http://papers.ssrn.com/sol3/papers.cfm?abstract_id=299420

FeLLER, W. (1971) “An Introduction to Probability Theory and its Applications", v.2, 2a edição. New York, John Wiley \& Sons.

KlOeCKNER, G. (1995) "Estudos de Evento: A análise de um método.", Revista Brasileira de Administração Contemporânea. v.1, n.2, set., p.261-270, 1995.

LA PORTA, R. ; LOPEZ-DE-SALINES, F. \& SHLEIFER, A. (2000) "Investor Protection and Corporate Governance", Journal of

Financial Economics, v.59, n.1-2, p.3-27 .

Rabelo, F. M \& Coutinho, L (2001) "Corporate Governance in Brazil”, OECD Development Centre -

http://www.oecd.org/dataoecd/9/62/2443323.pdf

RiBeiRo NETO, R. M. \& FAMÁ, R. (2001) "Eficiência de Mercado: O impacto da Nova Lei das Sociedades Anônimas Análise do Comportamento das Ações do Ibovespa no Período de 02/01/2001 a 09/04/2001”, Anais do V Semead http://www.fia.com.br/labfin/pesquisa/artigos/arquivos/233.pdf

SAITO, R. (2003) "Determinants of the Differential Pricing Between Voting and Non-Voting Shares in Brazil", Brazilian Review of Econometrics, v.23, n.1, p.23-40 